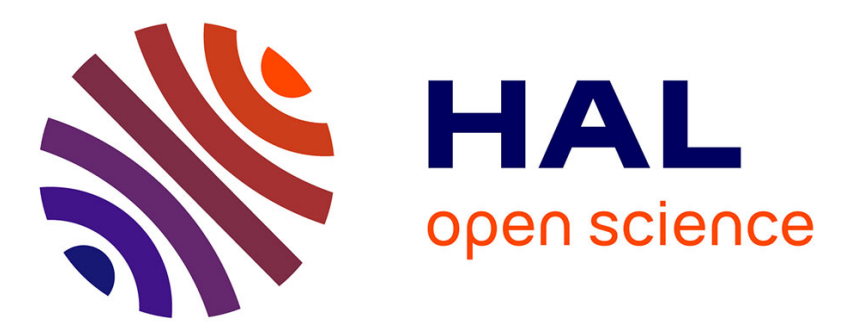

\title{
Successful treatment of Candida discitis with 5 -flucytosine and fluconazole
}

Satish M. Rachapalli, Ritu Malaiya, T. A. M. T. Mohd, Rod A. Hughes

\section{To cite this version:}

Satish M. Rachapalli, Ritu Malaiya, T. A. M. T. Mohd, Rod A. Hughes. Successful treatment of Candida discitis with 5-flucytosine and fluconazole. Rheumatology International, 2009, 30 (11), pp.15431544. 10.1007/s00296-009-1215-x . hal-00562263

\section{HAL Id: hal-00562263 https://hal.science/hal-00562263}

Submitted on 3 Feb 2011

HAL is a multi-disciplinary open access archive for the deposit and dissemination of scientific research documents, whether they are published or not. The documents may come from teaching and research institutions in France or abroad, or from public or private research centers.
L'archive ouverte pluridisciplinaire HAL, est destinée au dépôt et à la diffusion de documents scientifiques de niveau recherche, publiés ou non, émanant des établissements d'enseignement et de recherche français ou étrangers, des laboratoires publics ou privés. 
Title: Successful treatment of Candida Discitis with 5-Flucytosine and Fluconazole.

Authors:

S.M. Rachapalli, R Malaiya, TAMT Mohd, RA Hughes

\section{Institution:}

Department of Rheumatology, St Peter's Hospital, Chertsey, Surrey, UK

\section{Corresponding author:}

Dr Satish Rachapalli

Department of Rheumatology

St Peter's hospital

Surrey, UK

Tel: 01932723459

E mail: satishmohanreddy@yahoo.com 


\section{Case report:}

Intervertebral discitis is a rare but recognised complication of systemic candidaemia. Once diagnosed, treatment often consists of a prolonged course of amphotericin B and/or Fluconazole. We report a case of Candida discitis, successfully treated with Fluconazole and 5-Flucytosine.

A 48 year old Caucasian lady underwent a computerised tomography (CT) scan of chest to investigate chronic cough. This showed an incidental finding of inflammation of the inter-vertebral disc between sixth and seventh thoracic vertebrae. Three months prior to this admission she underwent a laparotomy for division of adhesions. Her postoperative period was complicated by severe sepsis requiring admission to the intensive care unit. Blood cultures at that time grew Staphylococcus aureus and Candida and she was treated with Vancomycin, Amphotericin B and Fluconazole.

During this admission, she complained of mid thoracic pain and did not have any features of systemic infection. She was on a combination of four different analgesics for the management of the pain. On examination, she had minimal tenderness over the mid thoracic region without neurological signs. Investigations showed a $\mathrm{C}$-reactive protein of $11 \mathrm{mg} / \mathrm{l}$, normal white cell count and bone profile. Blood cultures were sterile and Candida antigen was not detected. Protein electrophoresis was normal and urine was negative for Bence-Jones proteins. An isotope bone scan showed a hot spot at $6^{\text {th }}$ and $7^{\text {th }}$ thoracic vertebrae disc (T6/7) and a MRI scan revealed a high signal in the same area with surrounding oedema and soft tissue swelling, suggestive of discitis (Figure). A CT guided biopsy showed inflammatory cells comprising of plasma cells and periodic acid Schiff (PAS) staining confirmed presence of Candida hyphae.

Fluconazole $400 \mathrm{mg}$ once a day orally was commenced but she continued to complain of pain even after 2 weeks of treatment. Treatment was switched to intravenous Fluconazole and IV 5-Flucytosine for 2 weeks which resulted in symptomatic improvement and she was continued on oral Fluconazole $400 \mathrm{mg}$ for a further four weeks.

Candida discitis is a rare complication of systemic Candidaemia and is thought to spread haematogenously. ${ }^{2}$ To date, less than 60 such cases are reported. Invasive Candida infections have increased significantly over the past two decades ${ }^{3}$ and are commonly seen in immunosuppressed patients and intravenous drug users. The lack of typical inflammatory response and insidious course of the disease can make the diagnos is difficult.

The ideal duration for treatment of fungal discitis has not yet been established, and current practice is to continue therapy until clinical symptoms and inflammatory markers have normalised and/or imaging shows resolution of inflammation. Other treatment options include surgical intervention especially in cases of neurological compromise. ${ }^{1,6}$

Increasing resistance of Candida species has also been noted. Candida discitits is increasingly being noticed in severely ill patients with candidaemia previously exposed to azoles. ${ }^{3}$ Of note, no relationship between the duration of the initial treatment of candidaemia and the subsequent occurrence of late complications has 
been established. ${ }^{4}$ Evidence points towards Amphotericin IV being the first line agent of choice. ${ }^{4}$ However as Amphotericin is nephrotoxic, some authors prefer Fluconazole due to its favourable side effect profile. ${ }^{5}$ Currently Flucytosine is recommended for use in combination therapy in resistant cases of chronic disseminated candidiasis. ${ }^{3}$

This case shows that it is important to consider fungal discitis in patients with back pain and a history of candidaemia. 5-Flucytosine might be a useful agent in treating candida discitis in an era where resistance to other anti-fungal agents is increasing.

References:

1. Ugarriza LF, Cabezudo JM, Lorenzana LM, Rodríguez-Sánchez JA. Candida albicans spondylodiscitis. Br J Neurosurg. 2004 Apr;18(2):189-92.

2. Munk PL, Lee MJ, Poon PY, O'Connell JX, Coupland DB, Janzen DL, Logan PM, Dvorak MF. Candida osteomyelitis and disc space infection of the lumbar spine. Skeletal Radiol. 1997 Jan;26(1):42-6.

3. Pappas PG, Rex JH, Sobel JD, Filler SG, Dis mukes WE, Walsh TJ, Edwards JE. Guidelines for treatment of candidiasis. Clin Infect Dis 2004 Jan 15;38(2):161-89.

4. Pemán J, Jarque I, Bosch M, Cantón E, Salavert M, de Llanos R, Molina A. Spondylodiscitis caused by Candida krusei: case report and susceptibility patterns. J Clin Microbiol. 2006 May;44(5) : 1912-4.

5. Hennequin C, Bourée P, Hiesse C, Dupont B, Charpentier B. Spondylodiskitis due to Candida albicans: report of two patients who were successfully treated with fluconazole and review of the literature. Clin Infect Dis. 1996 Jul;23(1):176-8.

6. Miller DJ, Mejicano GC. Vertebral osteomyelitis due to Candida species: case report and literature review. Clin Infect Dis. 2001 Aug 15;33(4):523-30. 
Conflict of interest: None 
Figure: Magnetic resonance imaging of the spine showing inflammatory changes in the disc between $6^{\text {th }}$ and $7^{\text {th }}$ thoracic vertebrae

Legend for figure: Arrow showing the changes suggestive of discitis

Figure 1: Magnetic resonance imaging of the spine showing inflammatory changes in the disc between $6^{\text {th }}$ and $7^{\text {th }}$ thoracic vertebrae

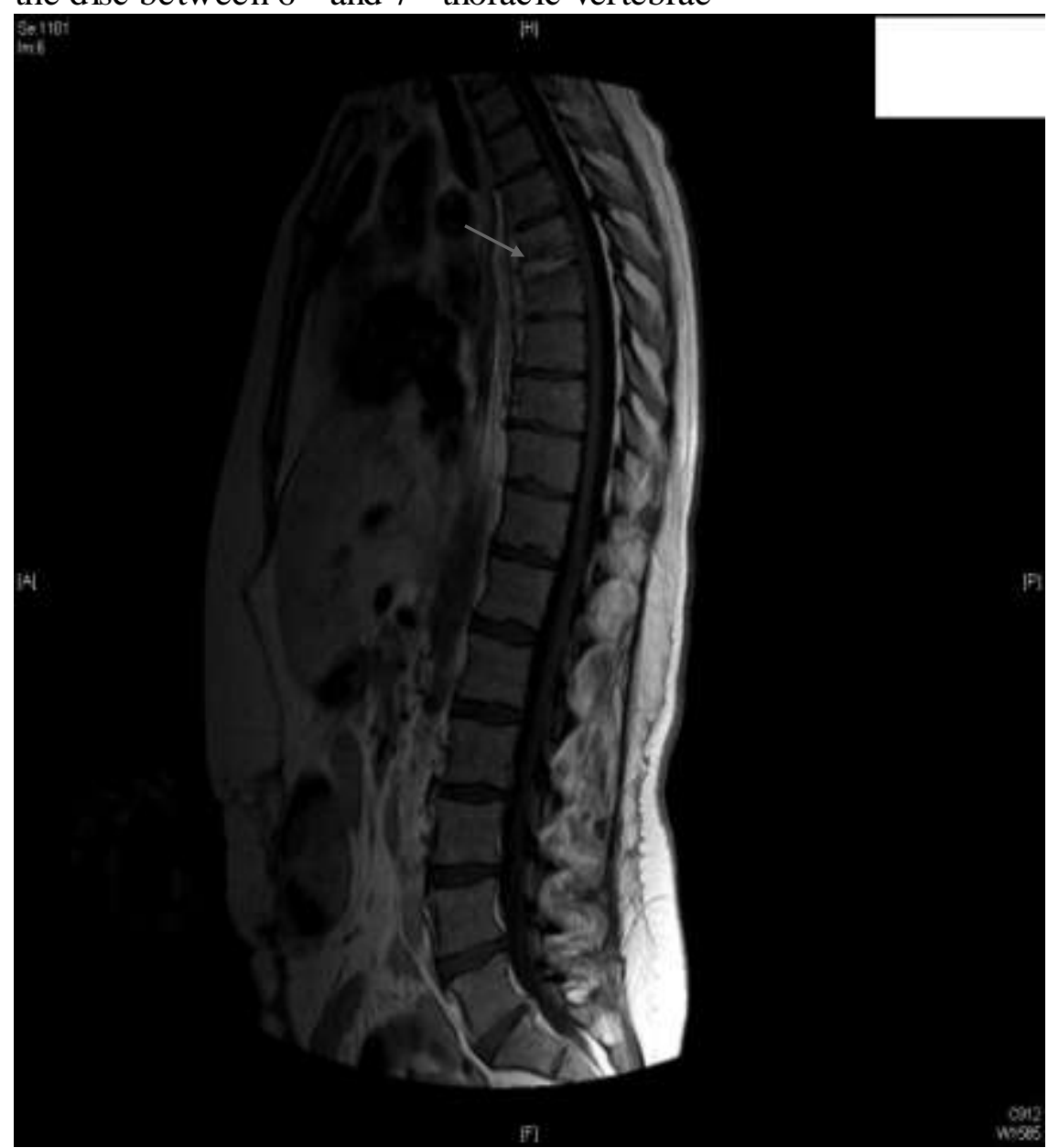

Legend: Arrow showing the changes suggestive of discitis 